\title{
Interplay of relational and contractual governance in public-private partnerships: The mediating role of relational norms, trust and partners' contribution
}

\author{
Camilo Benítez-Ávila ${ }^{\text {a,*}}{ }^{\text {, Andreas Hartmann }}{ }^{\text {a }}$, Geert Dewulf ${ }^{a}$, Jörg Henseler ${ }^{\mathrm{b}}$ \\ a Department of Civil Engineering, University of Twente, The Netherlands \\ ${ }^{\mathrm{b}}$ Department of Design, Production and Management, University of Twente, The Netherlands
}

Received 8 December 2016; received in revised form 8 December 2017; accepted 22 December 2017

Available online $\mathrm{xxxx}$

\begin{abstract}
Defining the nature of the relationship between contractual and relational governance is critical for understanding how to maintain commitment and coordination between private and public organizations in long-term partnerships. In this study, a theoretical model explains Public-Private Partnership (PPP) project performance as the result of a mediation process. Contractual and relational governance elements operate sequentially with relational elements (relational norms and trust), playing a mediating role between contractual elements, project actors' behaviour and final performance. Based on the analysis of a survey of PPP practitioners in The Netherlands, and using Consistent Partial Least Squares Modeling, the study provides empirical support for these mediating effects. The findings are aligned with the idea that both economic incentives and hierarchical relationships formalized in contract agreements require being internalized in working practices by means of informal and socially based mechanisms. The enabling and compensating mechanisms underlying the mediation role of relational governance elements are discussed. Managers can particularly find in relational norms a leverage point for designing collaborative day-to-day practices aimed at reinforcing trust and long-term contractual obligations.
\end{abstract}

(C) 2018 Elsevier Ltd. APM and IPMA. All rights reserved.

Keywords: Public-private partnerships; Contractual governance; Relational governance; Project governance; Trust; Relational norms; Partners' contribution

\section{Introduction}

Public-Private Partnership (PPP) projects have gained increasing popularity for organizing the economic transaction between public and private organizations in the provision of public infrastructure and other public assets (Boardman et al., 2015; OECD, 2012, p. 194). Nevertheless, existing literature suggests that establishing innovative contractual forms of economic

\footnotetext{
* Corresponding author.

E-mail addresses: c.a.benitezavila@utwente.nl (C. Benítez-Ávila), a.hartmann@utwente.nl (A. Hartmann),g.p.m.r.dewulf@utwente.nl

(G. Dewulf), j.henseler@utwente.nl (J. Henseler).
}

exchange between public and private sector does not automatically lead to improved performance. There is mixed evidence of the performance of PPPs in terms of delivering infrastructure on time and budget (Hodge and Greve, 2007, 2010, 2017; Van den Hurk and Verhoest, 2015), satisfying the needs of taxpayers and end-users (Hodge and Greve, 2010), providing flexibility along the project cycle (Blanken, 2008; Cruz and Marques, 2013), and providing satisfactory outcomes according to the perception of public and private managers (Verweij, 2015). PPP is not a magical contractual recipe to overcome typical governance problems of projects such as displaced agency, and their one-off, uncertain and highly asset-specific nature (Levitt et al., 2009). Furthermore, diverse levels of performance within similar contractual arrangements have brought up the relevance of idiosyncratic practices 
that are difficult to imitate between PPP projects, given their dependence on social, personal and informal relations (Bresnen and Marshall, 2002; Gibbons, 2010).

Contractual and relational governance are considered as different governance mechanism for triggering cooperative efforts to array project processes leading to performance and value for stakeholders (Levitt et al., 2014; Roehrich, 2009; Zheng et al., 2008). It is particularly the interplay between contractual and relational governance that has gained much attention and discussion in the study of inter-organizational arrangements (Cao and Lumineau, 2015; Poppo and Zenger, 2002). The original terms of the debate were defined by Poppo and Zenger (2002), who framed the contractual and relational governance interplay as a dichotomy between complementarity and substitution. Since then, scholars have researched the interplay to understand whether complementarity or substitution impacts on inter-organizational performance. The outcomes of these studies are not conclusive. For example in project management studies assessing "technical" and "Edgeworth" definitions of complementarity (Cao and Lumineau, 2015), ${ }^{1}$ "Edgeworth" complementarity has been supported for R\&D projects (Arranz and Arroyabe, 2012), software development projects (Gopal and Koka, 2012), and construction projects (Ke et al., 2015; Lu et al., 2015), and "technical" complementarity has been found in R\&D projects (Ryall and Sampson, 2009) and construction projects ( $\mathrm{Lu}$ et al., 2015). However, there is also evidence for "Edgeworth" substitution in the exploration phase of R\&D projects (Olander et al., 2010) and non-equity project alliances (Lui and Ngo, 2004). Given the existence of these inconsistent findings, it has been suggested that a more fruitful endeavor is the investigation of "how" and "when" relational and contractual governance interact in relation to project performance rather than striving for a definitive answer to "what" is the interplay (Cao and Lumineau, 2015).

In this context, the objective of this paper is providing a more fine-grained analysis of the interaction between contractual and relational governance in Public-Private Partnership (PPP) projects. More specifically, the paper intends to propose and test a theoretical model that explains PPP project performance as the result of a mediation process. There, contractual and relational governance elements operate sequentially with relational elements (relational norms and trust) playing a mediating role between contractual elements, project actors' behaviour and final performance. This consistent model is based on an overlooked proposition from seminal neoinstitutional theory (Zenger et al., 2000), according to which "formal institutions define the normative system designed by management or the blueprint for behaviour, [while] informal institutions define the actual behaviour of players" (Zenger et al., 2000, p. 5).

The paper contributes to the ongoing debate on contractual/ relational interplay by redirecting the discussion from the prevalent substitution/complementarity dichotomy to a sequential

\footnotetext{
${ }^{1}$ While technical definition focuses on the mutual relation between two variables (e.g. the increase of trust encourages the increase of contractual governance), Edgeworth focuses on the joint impacts of two variables in a third one (e.g. raising trust increases the returns to raising contractual governance for increasing project performance).
}

conceptualization along chains of mediated causality. Additionally, it also provides quantitative supporting evidence for PPP projects, where previous research has mainly used qualitative research strategies for addressing the contractual/relational interplay in PPPs (Bygballe et al., 2015; Hartmann et al., 2010; Rufín and Rivera-Santos, 2012; Strong and Chhun, 2014; Zheng et al., 2008) with few exceptions (Zhang et al., 2009). The proposed theoretical model is empirically validated by means of Consistent Partial Least Squares Structural Equation Modeling (PLSc-SEM), assessing the overall fit of the model for estimating measurement and structural model misspecification (Henseler et al., 2016). This validation is absent in the current literature examining the interplay of contractual and relational governance elements by means of SEM-PLS (Goo et al., 2009; Lu et al., 2015) making these studies and the obtained results rather exploratory in nature. However, the scope of the paper is limited to the interplay of governance elements at PPP project level excluding the wider institutional, cultural and policy context that may affect governance approaches. Furthermore, the empirical evidence is cross-sectional which cannot account for any feedbacks overtime between the different elements studied.

The paper is organized into four main sections. It starts off with the conceptual background, the introduction of the theoretical model and the related research hypotheses. In the second section, the research design is presented. It consists of a survey of private and public managers involved in PPP projects in the Netherlands as data collection approach, and PLSc-SEM as data analysis method. The third section presents the results of the data analysis, which support the mediating role of relational governance elements in PPP projects. In the fourth section the findings are discussed reframing the substitution/complementarity debate in the light of mediation analysis and process mechanisms (enabling/compensating). This section also includes managerial implications and limitations of the study. The paper ends with some concluding remarks.

\section{Contractual and relational governance in PPP projects}

The World Bank defines PPP as a "long-term contract between a private party and a government entity, for providing a public asset or service, in which the private party bears significant risk and management, and payment is linked to performance" (World-Bank, 2014, p. 19). This conceptualization ascribes to PPPs a particular set of formal rules with the capacity to ensure the delivery of public goods and services by defining obligations, roles and mission of a temporal coalition (Bygballe et al., 2013). However, contracts are only binding promises to act in the future under the expectation of value creation (Scott and Triantis, 2005), while the final project performance depends on the effective alignment of idiosyncratic public and private resources and activities towards the mission of the project (Kivleniece and Quelin, 2012). From a traditional governance perspective it is argued that an appropriate alignment of the formal rules to exchange condition is a sufficient behavioural driver for guaranteeing partners' contribution towards project performance (Chang, 2013).

However, practice and recent governance research indicate that relational governance elements are also crucial to the success of 
PPP projects (Tang et al., 2010). Literature differentiates between two elements of relational governance: relational norms and trust (Cao and Lumineau, 2015; Lu et al., 2015). Both are considered as relevant since they operate at different governance levels. While relational norms relate to values and social rules informally shared by project coalition members and, thus, operate external to a single individual (Macneil, 1980), trust is a psychological state of individual members of the project coalition (Kadefors, 2004). If these elements are brought together from a neoinstitutional organizational perspective a governance model can be proposed, that sees the role of contracts particularly in their influence on relational norms that subsequently trigger trust and directly steer partners' contribution towards project performance (Fig. 1).

From this perspective, contracts impact project performance by establishing a blue print of behaviour which defines the substantial content of the day-to-day relational rules for collaborating in projects (Zenger et al., 2000). In a PPP context, contractual provisions on risk transfer and payment linked to infrastructure availability constitute reference points for developing informal rules (relational norms) that allow managers to interact with each other and deal with project issues on a daily basis (Hart and Moore, 2008). Relational norms emphasize values such as communication, inclusion and open discussion using as a reference the PPP contract provisions, given the imperative of aligning accountability and transparency requirements from public administration with the profit-oriented rationality of private organizations (Ling et al., 2014). The operation of shared relational norms on managers' cooperative behaviour (partners' contribution) is then mediated by their psychological positive expectations about capacity and intention of their counterpart to comply with contractual roles and responsibilities. The operation of relational norms allows partners to mobilize resources and coordinate activities but also to build and reinforce trust. Then, trust further favours partners' contribution towards the mission of the project, which leads to project performance (Fig. 1).

A number of additional relations were controlled in order to assess the robustness of the proposed model. First, the direct relationship between contractual governance and partners' contribution and the direct relationship between contractual governance and project performance are included in the model. Second, project complexity is added as a moderator since it may influence the relationship strength between governance elements. Third, contractual governance can independently moderate the effect between relational norms and trust, as well the relationship between these relational elements and partners' contribution, and the relationship between partners' contribution and project performance. In the following, these relationships between the model constructs are further theoretically underpinned and the associated hypotheses are presented.

\subsection{Project performance and partners' contribution}

PPP agreements are the result of a process of negotiation and commitment between different social actors who may have competing values and eventually reach a shared vision based on the common idea that the materialization of a PPP project benefits their stakes (Hoezen, 2012). Thus, project performance is often conceptualized from the perspective of subjective satisfaction, given that different value claims and interests in projects lead to different perceptions of project success (Atkinson, 1999;

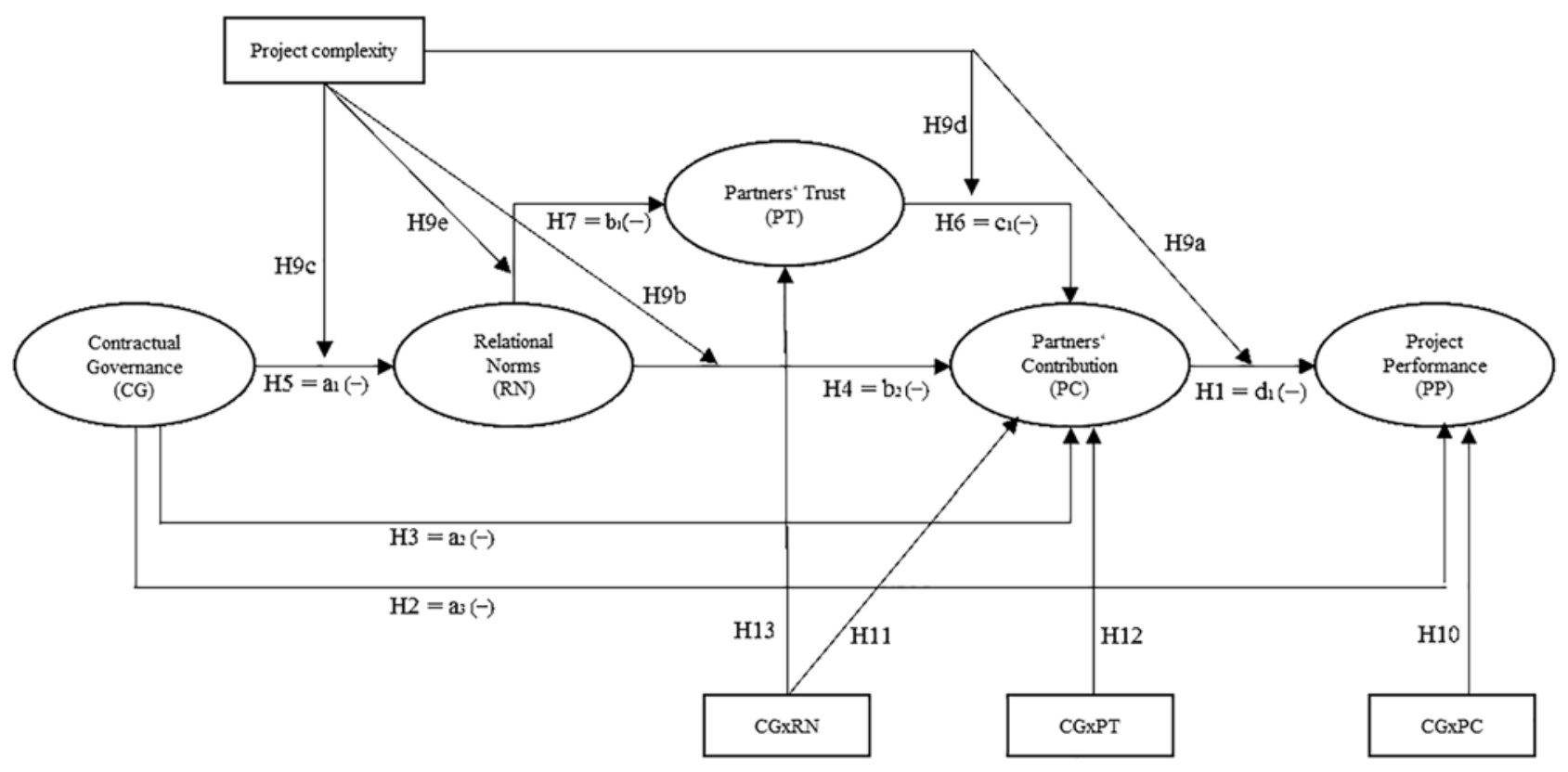

Indirect hyphotesis:

$\mathrm{H} 8: \mathrm{CG} \rightarrow \mathrm{RN} \rightarrow \mathrm{PC} \rightarrow \mathrm{PP}=\mathrm{a} 1 \mathrm{~b} 2 \mathrm{~d} 1$

$\mathrm{H} 8 \mathrm{a}: \mathrm{CG} \rightarrow \mathrm{RN} \rightarrow \mathrm{PC} \rightarrow \mathrm{PP}=\mathrm{a} 1 \mathrm{~b} 1 \mathrm{c} 1 \mathrm{~d} 1$
Moderators:

H9a H9e: Project complexity

$\mathrm{H} 10-\mathrm{H} 13$ : Contractual governance as independent moderator

Fig. 1. Structural model of contractual and relational governance in PPP projects. 
Table 1

Overall goodness of model fit (estimated model results).

\begin{tabular}{lcc}
\hline Criterion & Value & HI95 \\
\hline SRMR & 0.054 & 0.067 \\
$d_{U L S}$ & 0.398 & 0.608 \\
$d_{\mathrm{G}}$ & 0.172 & 0.249 \\
\hline
\end{tabular}

Aubry et al., 2011; Davis, 2014). In the field of Public-Private Partnerships, the multiplicity of stakes increases the ambiguity when measuring an overall "good outcome" (Verweij \& Gerrits, 2015). Furthermore, in the public sector "strategic objectives are not expressed in terms of profit and value to shareholders as in the private sector, but rather in terms of user satisfaction and value for a wide range of stakeholders, including politicians" (Aubry et al., 2011, p. 60). Defining a good outcome in PPPs is by no means straightforward, since many actors with different interests are involved (McGuire \& Agranoff, 2011). "Positive substantive outcomes are characterized by actors being satisfied based on their realized preferences and goals, and the time and energy spent achieving those preference and goals" (Verweij, Klijn, Edelenbos, \& Van Buuren, 2013, p. 1038).

Regardless the specific claims of value capture and subjective definition of satisfaction, members of the PPP project coalition have a mutual responsibility to contribute to the process of value co-creation (Bygballe et al., 2013). Final project outcomes require the coordination of individual contributions, in a continuous effort to array material processes by exploiting inter-organizational interdependences towards the completion of the project (Forsström, 2005; Thompson, 1967). It is important to clarify that partners' contribution cannot be defined a priori as part of relational governance, given that "cooperation does not necessarily require trust; it might be induced by coercion" (Kadefors, 2004, p. 176). Partners' contribution includes teamworking tasks and other activities for solving problems, disagreements and conflicts between parties involved in the project. Suprapto et al. (2015) provide quantitative evidence that the quality of teamworking processes positively impact project performance in the process industry. Likewise, Liu and Cross (2016) provide evidence of a positive relationship of cooperation and commitment between project teams and their outcomes. A positive correlation between cooperation and performance have been empirically supported for constructions projects (Ke et al., 2015), and innovation projects (Wu et al., 2017). Based on that, it is hypothesized that:

H1. Partners' contribution is positively associated with project performance.

\subsection{Contractual governance}

Contractual governance is regarded as a formal mechanism or constitutive rules defined in written documents and sanctioned through a formal position of authority and ownership (Zenger et al., 2000). Contractual governance is based on control in the extent to which collaboration and resulting project performance is the result of limiting the number of possible future project outcomes by allocating risks and setting enforceable standards aligned to the mission of the project (Brahm and Tarziján, 2015; Guo et al., 2014; Teisman et al., 2009; Zhang et al., 2016). Given that PPPs are single organizational arrangements between sovereign organizations (Borys and Jemison, 1989; Kivleniece and Quelin, 2012; Ménard, 1996), negotiated risk transfer and risk sharing regimes define legal responsibilities in the process of value co-creation (Bing et al., 2005; Chang, 2013; de Castro e Silva Neto et al., 2016; Grimsey and Lewis, 2002). In this regard, the existence of a third party legally entitled to resolve disputes according to contractual obligations is a guarantee for the delivery of contractual compromises (Chang, 2013; Das and Teng, 1998; Macneil, 1980). In their research, Ke et al. (2015) found such a positive impact of contractual governance in the supply chain performance of construction projects. It is thus hypothesized that:

H2. Contractual governance is positively associated with project performance.

Besides appealing to the control dimension, partners can use contracts as a point of reference for defining roles, coordinating activities and adapting the project to unforeseen circumstances without referring to corrective properties enforced by legal institutions (Hart and Moore, 2008; Schepker et al., 2014; Wang et al., 2017). In other words, PPP partners array coordinated contributions to the project based on clear specifications of what is allowed and what is not (Lu et al., 2015). Luo (2002) shows that cooperation is subject to the influence of contractual design, while Xue et al. (2016) reach the same conclusion for joint-venture megaprojects with low levels of interpersonal relationships. Similarly, contract characteristics such as term specificity, adaptability and obligatoriness are found to negatively correlate with opportunism according to managers of construction projects (Lu et al., 2016). Based on that, it is hypothesized that:

H3. Contractual governance is positively associated with partners' contribution.

\subsection{Relational governance elements}

\subsubsection{Relational norms}

Relational norms are informal rules of social exchange such as flexibility, solidarity, participation in decision-making, communication and problem-solving through consultation (Kaufmann and Dant, 1992; Macneil, 1980; Xue et al., 2016). In the PPP context, relational norms emphasize the need to openly discuss and involve different perspectives for addressing project issues, given the diverse nature of public and private organizational logics (Rufin and Rivera-Santos, 2012; Villani et al., 2015), and the tacit concern of public transparency (Ke et al., 2013; Ling et al., 2014; Ning and Ling, 2013). Accountability is crucial in the development of relational norms in PPPs (Klijn and Koppenjan, 2016; Klijn et al., 2010), in order to avoid allegations of corruption from close relationships between public and private managers (Ke et al., 2013; Ling et al., 2014). Commitment and collaboration based on tacit understandings on how to organize team work on daily basis lead to project predictability 
Table 2

Factor assessment and results.

\begin{tabular}{lllll}
\hline Factor construct & $\left(P_{A}\right)$ & AVE & Item & \\
\hline Partners' contribution & 0.75 & $0.48^{\mathrm{a}}$ & PC1 & $\begin{array}{l}\text { Activities of the involved parties are coordinated (aligned) } \\
\text { The involved contract partners have contributed to the completion } \\
\text { of the project in an accurate way } \\
\text { The involved organizations in the network have adequate ways to } \\
\text { command mutual disagreements and conflicts successfully } \\
\text { During the past years, parties have improved their collaboration }\end{array}$ \\
\hline
\end{tabular}

${ }^{a}$ Second test: eigenvalue highest outload $1.94>0$; and lowest outload $0.64<0$.

b Item eliminated in order to increase Convergent Validity.

(Lu et al., 2015; Suprapto et al., 2015). Evidence from Dutch process industry projects indicates a positive relationship between relational norms, relational attitudes and team working quality (Suprapto et al., 2015), while joint planning and solving problems are positively correlated with relational norms (Zhou et al., 2015). Based on that, it is hypothesized that:

H4. Relational norms are positively associated with partners' contribution.

Informal rules can be influenced by the intentional manipulation of formal institutions, being the latter a vehicle to steer behaviour (Lincoln, 1982; Stevenson, 1990). Contracts define a number of formal rules, operating as a point of reference for encouraging the development of informal relational norms (Cao and Lumineau, 2015; Hart and Moore, 2008). Chen and Manley (2014) provide evidence that the intensity of formal mechanisms is positively associated with the implementation of informal mechanisms in infrastructure projects. Based on that, it is hypothesized that:
H5. Contractual governance is positively associated with relational norms.

\subsubsection{Partners' trust}

Trust refers to a "psychological state comprising the intention to accept vulnerability based upon positive expectations of the intentions or behaviour of another" (Rousseau, Sitkin, Burt, \& Camerer, 1998, p. 395). As value creation at project level depends on the capability to mobilize, coordinate and adjust various actors towards a well-defined objective in a clear boundary setting (Bygballe et al., 2013), trust facilitates the process of collaboration by means of increasing mutual reliability on individual contributions to the conclusion of the project (Kadefors, 2004; Wu et al., 2017). Then, project performance is the result of sustained collaboration triggered by the unspecified obligation of reciprocity based on trust (Blau, 1964). Trust permits partners to discard negative consequences in the future upon the confidence of a positive outcome and based on the expectation that others refrain from

Table 3

Composites assessment and results.

\begin{tabular}{|c|c|c|c|c|}
\hline \multirow{2}{*}{$\frac{\text { Composite construct }}{\text { Contractual governance }}$} & \multicolumn{2}{|c|}{ Indicator } & \multirow{2}{*}{$\frac{\text { Weight }}{0.275}$} & \multirow{2}{*}{$\begin{array}{l}\mathrm{T} \text {-values } \\
1.23\end{array}$} \\
\hline & CG1 & The contract is simple to understand ${ }^{\mathrm{a}}$ & & \\
\hline & CG2 & The contract has many possibilities for imposing sanctions if the contract terms are not met & 0.640 & 3.13 \\
\hline & CG3 & The contract is characterized by fixed target values and norms regardless of the circumstances ${ }^{\mathrm{b}}$ & NA & NA \\
\hline & CG5 & Financial risk is shared between public and private partners & 0.507 & 2.29 \\
\hline \multirow[t]{6}{*}{ Project relational norms } & RN1 & There are organizational arrangements to facilitate interaction between parties & 0.242 & 1.81 \\
\hline & RN2 & (Private) implementers are consulted and involved in decisions of the project management & 0.265 & 1.81 \\
\hline & RN4 & In the decision-making process about the different project, views are made visible and included & 0.417 & 3.79 \\
\hline & RN5 & Time is spent in communicating between parties (contract parties and external parties) ${ }^{\mathrm{b}}$ & NA & NA \\
\hline & RN6 & $\begin{array}{l}\text { During information collection, emphasis was placed on establishing common starting points, } \\
\text { and common information needs }{ }^{\text {b }}\end{array}$ & NA & NA \\
\hline & RN7 & $\begin{array}{l}\text { When deadlock was reached, or problems arose in the project, management tried to find common } \\
\text { ground between the conflicting interests }\end{array}$ & 0.479 & 3.19 \\
\hline & PP5 & The cost of the project stays within the limits that have been set & 0.426 & 2.92 \\
\hline & PP6 & In general, the benefits exceed the costs ${ }^{\mathrm{b}}$ & NA & NA \\
\hline
\end{tabular}

${ }^{a}$ Indicator retained regardless non-significant weight, as it increases SRMR score.

b Indicator eliminated duet to non-significant weight. 


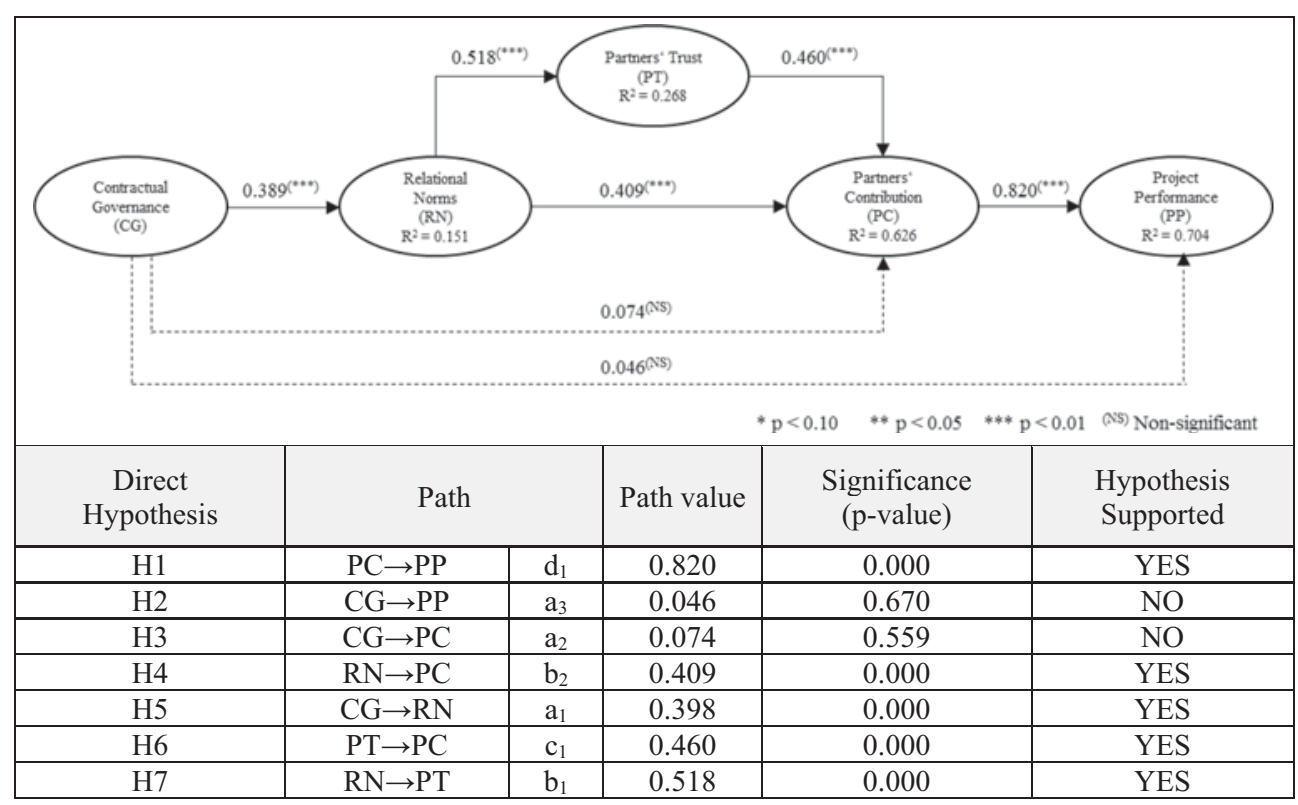

Fig. 2. Results for the structural model and direct hypothesis.

opportunistic behaviour (Meng, 2012; Tang et al., 2010; Teisman et al., 2009). Wu et al. (2017) provide evidence that relational trust positively impacts cooperative behaviours in high-tech projects, while it is negatively correlated with opportunistic behaviours. In a similar way, Ke et al. (2015) found a significant positive relationship between trust and cooperation in construction projects. Based on that, it is hypothesized that:

H6. Partners' trust is positively associated with partners' contribution.

Relational norms furnish partners' trust taking into consideration that projects are temporal and highly coupled systems embedded in long-term and loosely coupled systems (Dubois \&

Table 4

Direct, indirect and total effects between constructs. *

\begin{tabular}{|c|c|c|c|c|c|}
\hline $\begin{array}{l}\text { Precursor } \\
\text { variable }\end{array}$ & Effect & $\begin{array}{l}\text { Relational } \\
\text { norms }\end{array}$ & $\begin{array}{l}\text { Partners' } \\
\text { trust }\end{array}$ & $\begin{array}{l}\text { Partners' } \\
\text { contribution }\end{array}$ & $\begin{array}{l}\text { Project } \\
\text { performance }\end{array}$ \\
\hline \multirow{3}{*}{$\begin{array}{l}\text { Contractual } \\
\text { governance }\end{array}$} & Direct & $0.389 * * *$ & & $0.074^{(\mathrm{NS})}$ & $0.046^{\text {(NS) }}$ \\
\hline & Indirect & & $0.202 * * *$ & $0.252 * * *$ & $0.267 * *$ \\
\hline & Total & $0.389 * * *$ & $0.202 * * *$ & $0.326 * * *$ & $0.314 * * *$ \\
\hline \multirow{3}{*}{$\begin{array}{c}\text { Relational } \\
\text { norms }\end{array}$} & Direct & & $0.518 * * *$ & $0.409 * * *$ & \\
\hline & Indirect & & & $0.238 * * *$ & $0.530 * * *$ \\
\hline & Total & & $0.518 * * *$ & $0.647 * * *$ & $0.530 * * *$ \\
\hline \multirow[t]{3}{*}{ Partner trust } & Direct & & & $0.460 * * *$ & \\
\hline & Indirect & & & & $0.377 * * *$ \\
\hline & Total & & & $0.460 * * *$ & $0.377 * * *$ \\
\hline \multirow{3}{*}{$\begin{array}{l}\text { Partners' } \\
\text { contribution }\end{array}$} & Direct & & & & $0.820 * * *$ \\
\hline & Indirect & & & & \\
\hline & Total & & & & $0.820 * * *$ \\
\hline
\end{tabular}

$* p<0.10$.

$* * \mathrm{p}<0.05$.

$* * * \mathrm{p}<0.01$.

NS Non-significant.
Gadde, 2002). This embeddedness implies a complex grid of relational, sequential and pooled interdependencies as pre-existing trust factors of project coalitions (Bygballe et al., 2013). Formal contracts define the relational boundaries of a temporal project coalition imposing specific obligations, interaction rules and close interdependencies over long-lasting relationships in the network. Relational norms at project level reinforce pre-existing levels of trust between members of a project coalition. For global project teams, Henderson et al. (2016) provide evidence that perceptions of the alignment of informal rules in communication impact the levels of inter-personal trust. Based on that, it is hypothesized that:

H7. Relational norms are positively associated with partners' trust.

Table 5

PLS -two-stage moderation analysis - project complexity.

\begin{tabular}{llll}
\hline $\mathrm{H}$ & Direct relationship & Baseline model & Moderation model \\
\hline $\mathrm{H} 1$ & $\mathrm{PC} \rightarrow \mathrm{PP}$ & $0.820^{* * *}$ & $0.672^{* * *}$ \\
$\mathrm{H} 9 \mathrm{a}$ & & & $0.147^{* *}$ \\
$\mathrm{H} 4$ & $\mathrm{RN} \rightarrow \mathrm{PC}$ & $0.409^{* * *}$ & $0.349^{* * *}$ \\
$\mathrm{H} 9 \mathrm{~b}$ & & & $0.048^{(\mathrm{NS})} *$ \\
$\mathrm{H} 5$ & $\mathrm{CG} \rightarrow \mathrm{RN}$ & $0.398^{* * *}$ & $0.369^{* * *}$ \\
$\mathrm{H} 9 \mathrm{c}$ & & & $0.182^{* *}$ \\
$\mathrm{H} 6$ & $\mathrm{PT} \rightarrow$ PC & $0.460^{* * *}$ & $0.392^{* * *}$ \\
$\mathrm{H} 9 \mathrm{~d}$ & & & $0.051^{(\mathrm{NS})}$ \\
$\mathrm{H} 7$ & $\mathrm{RN} \rightarrow \mathrm{PT}$ & $0.518^{* * *}$ & $0.483^{* * *}$ \\
$\mathrm{H9e}$ & & & $0.123^{(\mathrm{NS})}$ \\
\hline
\end{tabular}

\footnotetext{
NS Non-significant.

$* p<0.10$.

$* * \mathrm{p}<0.05$

$* * * \mathrm{p}<0.01$.
} 
Table 6

PLS -two-stage moderation analysis - contractual governance.

\begin{tabular}{llll}
\hline $\mathrm{H}$ & Direct relationship & Baseline model & Moderation model \\
\hline $\mathrm{H} 1$ & $\mathrm{PC} \rightarrow$ PP & $0.820 * * *$ & $0.679 * * *$ \\
$\mathrm{H} 10$ & & $0.002^{(\mathrm{NS})}$ \\
$\mathrm{H} 4$ & $\mathrm{RN} \rightarrow \mathrm{PC}$ & $0.409 * * *$ & $0.354 * * *$ \\
$\mathrm{H} 11$ & & & $-0.000^{(\mathrm{NS})}$ \\
$\mathrm{H} 6$ & $\mathrm{PT} \rightarrow$ PC & $0.460 * * *$ & $0.389^{* * *}$ \\
$\mathrm{H} 12$ & & & $-0.074^{(\mathrm{NS})}$ \\
$\mathrm{H} 7$ & $\mathrm{RN} \rightarrow$ PT & $0.518^{* * *}$ & $0.522^{* * *}$ \\
$\mathrm{H} 13$ & & & $0.043^{(\mathrm{NS})}$ \\
\hline
\end{tabular}

NS: Non-significant. $* p 0.10 .{ }^{* *} p * * * \mathrm{p}$.

\subsection{Relational governance elements as mediators of contractual governance}

The mediating role of relational governance elements is based on the limited ability of formal rules to support exchange in comparison to informal rules and trust influencing behaviour (Granovetter, 1985; Scott, 1983). Contracts indirectly foster cooperation by promoting relational practices for mitigating misunderstandings. (Hoecht, 2004; Malhotra and Murnighan, 2002; Ring and Van de Ven, 1994). Based on research on collaborative infrastructure projects, Chen and Manley (2014) provide evidence that formal governance mechanisms are positively correlated with informal governance mechanisms, the latter mediating the impact of the former on project performance. Likewise, (Goo et al., 2009) provide evidence that contractual governance forms positively influence informal relational norms, being the latter a mediator between the former and partners' commitment in the context of software projects. Based on that, and taking into account the relationships defined in $\mathrm{H} 1, \mathrm{H} 4$ and $\mathrm{H} 5$ it is hypothesized that:

H8. The relationship between contractual governance and project performance is mediated by relational norms and partners' contribution.

Research based on institutional theory have provide evidence that trust also plays a mediating role between organizational norms and collaborative practices (Wang et al., 2014). In the context of contractual relations, focusing on formal roles and responsibilities favours a climate of fairness and informal practices that reinforce trust, leading to collaboration (Das and Teng, 1998; Dyer and Chu, 2003; Eshuis and Van Woerkum, 2003; Yang et al., 2012). Therefore, and taking into account H1, H5, H6 and H7:

H8a. The relationship between contractual governance and project performance is mediated by relational norms, partners' trust and partners' contribution.

Project complexity can moderate the relationship between contractual and relational governance elements. As Kivleniece and Quelin (2012) have shown, a closer relational interaction between public and private parties is more important when higher levels of complexity are perceived, including technological complexity, external uncertainty and high exposure to social activism from stakeholders. When technological complexity, uncertainty and exposure to social activism are low, the value co-creation process can rely on a contractual-oriented mode of governance (Kivleniece and Quelin, 2012). It is thus hypothesized that:

H9a. Project complexity positively moderates the relationship between partners' contribution and project performance.

H9b. Project complexity positively moderates the relationship between relational norms and partners' contribution.

H9c. Project complexity positively moderates the relationship between contractual governance and relational norms.

H9d. Project complexity positively moderates the relationship between partners' trust and partners' contribution.

H9e. Project complexity positively moderates the relationship between relational norms and partners' trust.

Finally, previous research based on the dichotomy perspective of the contractual/relational interplay has found that contractual governance can operate as an independent moderator. In particular, it can moderate the effect of relational governance elements on partners' behaviours and project performance (Poppo and Zenger, 2002). Even when contractual governance positively influences relational governance elements such as relational norms, paradoxically, higher levels of contractual governance can dampen at the same time "the level of trust and commitment through moderation effects" (Goo et al., 2009, p. 119). As there is also evidence indicating that this moderating effect can be present (Cao and Lumineau, 2015), the following hypothesis are additionally considered:

H10. Contractual governance moderates the relationship between partners' contribution and project performance.

H11. Contractual governance moderates the relationship between relational norms and partners contribution.

H12. Contractual governance moderates the relationship between partners' trust and partners' contribution.

H13. Contractual governance moderates the relationship between relational norms and partners' trust.

\section{Research design}

This study uses a confirmatory theory testing approach, which implies either accepting or rejecting a hypothesized structural model based on the statistical assessment of empirical evidence (Henseler et al., 2016). The structural model comprises direct and indirect relations between five constructs and moderating effects of project complexity and contractual governance (Fig. 1). 
The unit of analysis is the governance structure and governing activity in PPP projects, and the unit of observation are managers working in these projects. Managers are considered as "key informants" (Goo et al., 2009; Segars and Grover, 1998), since they have first-hand information on project organization properties and their day-to-day activities are shaped by the formal and informal rules of the project (Zenger et al., 2000).

\subsection{Survey and data collection}

Data was collected through a survey of private and public managers involved in officially known PPP projects in The Netherlands, aiming at the whole population of ongoing projects. The covered PPPs included infrastructure, regional development projects and real estate projects. They were selected from official government documents and PPP advisory organizations. Respondents were identified based on the documents, the project websites and other information sources of the projects. To increase the possibility that a project is covered, for each project more than one person was selected with a maximum of three individuals involved in one project. Of the 343 public and private managers of 93 PPP projects that received the questionnaire ten respondents could not be reached (mail undeliverable) and 24 persons indicated that they would not like to fill in the survey or were not involved in the project. From the remaining 309 persons, 157 participated in the survey. 14 questionnaires were not completed and thus deleted from the initial data set. The 144 respondents (response percentage of 46.3\%) included in the analysis represent 68 PPP projects, covering $73 \%$ of PPP projects identified in The Netherlands. Respondents were employed in private consortia $(27.1 \%)$, consultancies $(13.2 \%)$, public organizations $(45.8 \%)$ and other organizations $(11.8 \%)$ such as non-profit organizations and law firms.

Regarding the level of variance explained by projects, a one-way M-ANOVA analysis was carried out for the data points for which respondents explicitly named the project $(n=128)$. Based on the analysis, there was a statistically significant difference between projects $(\mathrm{F}(848,573)=1.341, p=0.000$; Wilk's $\Lambda=$ 0.000 , partial $\eta 2=0.649$ ). This indicates that about two thirds of the variance can be attributed to inter-project variance, whereas one third can be attributed to intra-project variance. Common method bias was tested using PLS marker approach (Rönkkö and Ylitalo, 2011), indicating that significant paths in the baseline model were also significant in the marker variable model. This evidence dissipates concerns about the common method bias.

\subsection{Method}

Consistent Partial Least Squares - Structural Equation Modeling (PLSc-SEM) was selected as a variance-based method to test hypothesized relations. PLS-SEM in general allows to assess non-direct causal relationships between variables, incorporating auxiliary measurement theories or non-observable/latent variables measured indirectly by empirical indicators, and overcoming the need to impose restrictions on data, such as distribution assumptions required by other SEM techniques based on probability theory (Hair et al., 2013). PLSc-SEM in particular remedies the adverse consequences of using ordinary PLS when estimating common factor models for hypothesis testing, which have supported the claim that variance-based SEM methods are less suitable for hypothesis testing comparing to covariance-based SEM methods (Dijkstra and Henseler, 2015). Updated guidelines for using PLSc path modeling developed by Henseler et al. (2016) were used to assess the model. According to the guidelines, results should be first assessed globally (overall model), and then locally (measurement models and structural model). The PLSc-SEM algorithm was run using 4.999 bootstrap samples to determine the likelihood of obtaining a discrepancy between the empirical and the model-implied correlation, and estimating direct and indirect effects for conducting mediation analysis.

\subsection{Measurement model}

\subsubsection{Contractual governance (exogenous - composite)}

The measure includes five items, scored on a 1-10 scale between two dichotomic statements derived from literature. The variable is modelled as composite as it emerges from the particular configuration of different contractual attributes: control, coordination and adaptation (Schepker et al., 2014). Two items address the control dimension sanctioned upon legal obligations: CG1-Complexity: (From 1- 'The contract is difficult to understand" to 10- "The contract is easy to understand"), CG2-Sanction: (From 1- "The contract has no possibilities for imposing sanctions if the contract terms are not met" to 10- "The contract has many possibilities for imposing sanctions if the contract terms are not met"). Two items address the coordinating dimension of the contract to adapt project to unforeseen circumstances: - CG3-Flexibility: (From 1- "The contract is characterized by fixed target values and norms regardless of the circumstances" to 10 -"The contract is characterized by flexible target values and norms that can be reduced or enhanced under certain circumstances"), and CG4-Negotiation: (From 1- "The contract offers very little space for negotiation" to 10 - "The contract offers much space for negotiation"). Finally, subscribing that the core of a PPP contract is transferring or negotiating project risks (Chang, 2013), the final indicator is - CG5-Risk sharing: (From 1 "Financial risk is not shared between partners to a great extent" to 10 - "Financial risk is shared between partners").

\subsubsection{Project relational norms (endogenous - composite)}

The measure includes seven indicators derived from the literature (scoring a statement from a 1-5 scale, where one is "totally disagree" and five is "totally agree"). The first indicator refers to general norms as non-binding rules for organizing public and private relations following the general tenets of Kaufmann and Dant (1992) and Macneil (1980) RN1 - "There are organizational arrangements to facilitate interaction between parties". The other six indicators are retrieved from Klijn et al. (2010), who specify indicators on informal norms to govern relations in public-private networks. Two indicators measure the involvement of key actors for addressing project issues: - RN2- Contractor involvement: "(Private) contractors are consulted and involved in project management decisions", and - RN3-Stakeholder involvement: 
"Attention has been paid to the involvement of external stakeholders (citizens, environmental groups, other public actors) and their opinions". Two indicators address transparency, RN4-Perspective diversity: "In the decision-making process about the project different views are included and made visible", and - RN5-Communication effort: "Time is spent in communicating between parties (contract parties as well external parties)". Finally, two indicators measure the norms for solving problems by means of consultation - RN6-Common basis: "During information collection, emphasis was placed on establishing common starting points and common information needs between public and private parties in this project", and - RN7-Problem solving: "When deadlock was reached, or problems arose in the project, the project management tried to find common ground between the conflicting interests".

\subsubsection{Partners' trust (endogenous - single item)}

The measure considers trust as a psychological state of mutual reciprocity based upon positive expectations of others intentions (Kadefors, 2004). A single measure is used (10-point Likert scale between two between two dichotomic statements) to capture this psychological state - PT1-Trust: (From 1- "There is no trust between the public and private parties" to 10 "There is much trust between the public and private parties"). The high level of abstraction of a single-item allows measuring the attitudinal nature of trust, irrespectively of their source or dimension. This approach is suggested by Medlin and Quester (2002), who argue that due to the difficulties in the operationalization and measurement of inter-organizational trust and its suggested dimensions, it could and should be treated as a one-dimensional, global measure. The selection of a one-single item to measure trust is common in the design of National surveys on trust and Social capital, such as the one conducted by the National Opinion Research Center's General Social Survey (Glaeser, Laibson, Scheinkman, \& Soutter, 2000).

\subsubsection{Partners' contribution (endogenous - factor)}

"Partners Contribution" measures the actual behaviour of cooperation between partners during the process of completing and delivering the project (Procaccino et al., 2005), irrespective of its source (coercion, economic incentives or trust) (Kadefors, 2004). This construct is measured with four items, on a scale from 1 to 5 where one is "totally disagree" and five is "totally agree". These items are used to measure process outcomes in the context of projects involving networks of public and private organizations and other types of stakeholders (Klijn et al., 2010): - PC1: "Activities of the involved parties are coordinated (aligned)", - PC2: "The involved contract partners have contributed to the completion of the project in an accurate way", - PC3: "The involved organizations in the network have adequate ways to command mutual disagreements and conflicts successfully", and - PC4: "During the past years, parties have improved their collaboration". As a factor, it reflects the measured variance of its corresponding indicators assuming that they reflect an underlying common concept based on true score theory (Henseler et al., 2016, p. 3).

\subsubsection{Project performance (endogenous - composite)}

The measure includes six items (scored on a 1-5 scale, where one is "totally agree" and five is "totally disagree") taking into account the diversity of projects examined (infrastructure, regional development projects and real estate projects), and assuming that performance emerges from the configuration of different definitions of value (Ahola et al., 2014). The first item measures the general satisfaction taking into account different value claims and interests (Aubry et al., 2011): - PP1: "The project solutions are sufficiently supported by the organizations involved". The rest of items measures the satisfaction in terms of functionality, quality and efficiency (Winch, 2010). Two items measure functionality: - PP2: "Different spatial functions have been connected sufficiently in the project", and - PP3: "Solutions developed in the project truly deal with the problems at hand". One item measures quality overtime: - PP4: "Developed solutions in the project are durable for the future". Two items measure economic efficiency: - PP5: "The costs of the project stay within the limits that have been set", and - PP6: "In general, the benefits of the project exceed the costs".

\subsubsection{Perceived project complexity (moderator - composite)}

The measure includes three items, scored on a 1-10 scale between two dichotomic statements:- CPLX1: Technological complexity (from 1 "The project was characterized by low technological complexity" to 10- "The project was characterized by high technological complexity"), CPLX2: External conditions (From 1 - "The project is hardly affected by external conditions - for instance like safety regulations, nature requirements, etc." to 10- "The project is strongly affected by external conditions - for instance like safety regulations, nature requirements, etc."). CPLX3 External stakeholders (From 1"The project was characterized by a low number of external stakeholders" to 10- "The project was characterized by a high number of external stakeholders").

\section{Results}

\subsection{Overall fit of the model}

Three general tests were conducted to identify both, measurement model misspecification and structural model misspecification: maximum likelihood discrepancy $(S R M R)$, the geodesic discrepancy $d_{\mathrm{G}}$, and unweighted least squares discrepancy $d_{U L S}$ (Table 1). As resulting values should be lower than the selected bootstrap quantile, the model met the criteria for HI95 quantile. Furthermore, the model score for SRMR is 0.054 which suggests a good overall fit, taking into account that a value of 0 for SRMR would indicate a perfect fit and a value lower than 0.08 indicates an acceptable fit.

\subsection{Measurement model}

For factor constructs, the most relevant internal consistency reliability measure in PSLc modeling is Dijkstra-Henseler's rho (PA), which should be higher than 0.7 (Dijkstra and Henseler, 2015). The factor construct partners' contribution scored 0.75 
PA, implying an acceptable amount of random error. For convergent validity, the usual measure is the Average Variance Extracted (AVE) that should be higher than 0.5 to be considered acceptable. Given that the AVE factor scored 0.48, there is the possibility that the factor construct was not able to extract a dominant factor. Therefore, a second test was carried for assessing unidimensionality following the method of Sahmer et al. (2006) based on Kaiser (1992) rule. It consists of evaluating a factor construct as unidimensional if the eigenvalue of the higher outload is larger than 1 and the second eigenvalue of the smallest outload is smaller than 1 . With a bootstrap size of 100,000 , the eigenvalue of the highest outload was 1.94, while the eigenvalue of the lowest outload was 0.642 providing evidence on convergent validity. It was not necessary testing discriminant validity, taking into account that the model only includes one factor construct. Indicators were excluded when their outer loads were smaller than 0.4 (Churchill, 1979) and construct reliability or validity could be increased (Table 2). ${ }^{2}$

For assessing reliability and validity of composite constructs the major point of departure is the confirmatory composite analysis (Henseler et al., 2014), which assessment was carried out when evaluating the overall model-fit (SRMR $<95 \%$ bootstrap HI95 quantile, see Table 1). ${ }^{3}$ For collinearity, the assessment of the Variance Inflation Factor (VIF) revealed values below 2.0 for all indicators discarding collinearity issues. Indicators were excluded when their outer weight was not significant (T-value below $1.65(\alpha=0.10)$ ), except when keeping the indicator would increase the confirmatory composite analysis score (SRMR score) as PLSc defines consistency at large (Table 3).

\subsection{Structural model and hypothesis testing}

The central criterion for assessing the structural model is accounting for the coefficient of determination $\mathrm{R}^{2}$, which measures the explanatory power of the model in terms of the variation in the endogenous constructs (Fig. 2). According to adjusted $\mathrm{R}^{2}$ assessment of the endogenous variables, the percentage of variation explained for relational norms and partners' trust is rather weak, and stronger for partners' contribution and project performance. ${ }^{4}$ In order to provide a detailed picture of the theory tested, the analysis is organized in three steps: (a.) assessing direct relationships; (b.) classifying mediations (and no-mediations) according to the typology established by Zhao et al. (2010); and, (c.) assessing compound

\footnotetext{
${ }^{2}$ Given that PLSc defines consistency at large "one should be careful when eliminating indicators. Only if an indicator's reliability is low and eliminating this indicator goes along with a substantial increase of construct reliability, it makes sense to discard this indicator" (Henseler et al., 2009, p. 299).

${ }^{3}$ Confirmatory composite analysis can be regarded as a pragmatic criteria for detecting measurement model specification, as it "determines the exact fit of the composite factor model by means of bootstrapping the conventional likelihood function" (Henseler et al., 2014, p. 194).

4 "In scholarly research that focuses on marketing issues, $\mathrm{R}^{2}$ values of 0.75 , 0.50 , or 0.25 for endogenous latent variables can, as a rough rule of thumb, be described as substantial, moderate, or weak" (Hair et al., 2013, p. 175).
}

paths by means of direct, indirect and total effects. Results provide support to $\mathrm{H} 1, \mathrm{H} 4, \mathrm{H} 5, \mathrm{H} 6$, and $\mathrm{H} 7$ but they do not support $\mathrm{H} 2$ and $\mathrm{H} 3$ (Fig. 2). The evidence of these direct effects provides support for the hypothesis H8 and H8a. Additionally, Annex 1 presents inter-construct correlations.

The strongest direct relationships are estimated for $\mathrm{H} 1$ and $\mathrm{H} 7,{ }^{5}$ according to which partners' contribution has a positive effect on project performance $\left(\mathrm{d}_{1}=0.820, p<0.01, \mathrm{f}^{2}=\right.$ $2,05)$; and, relational norms have a positive effect on partners' trust $\left(\mathrm{b}_{1}=0.518, p<0.01, \mathrm{f}^{2}=0.37\right)$. Moderate relationships are estimated for $\mathrm{H} 6\left(\mathrm{c}_{1}=0.460, p<0.01, \mathrm{f}^{2}=0.26\right)$, H4 $\left(\mathrm{b}_{2}=0.409, \mathrm{p}<0.01, \mathrm{f}^{2}=0.20\right) \quad$ and $\mathrm{H} 5 \quad\left(\mathrm{a}_{1}=0.398\right.$, $\left.\mathrm{p}<0.01, \mathrm{f}^{2}=0.17\right)$.

\subsubsection{Mediation hypothesis $H 8$ and $H 8 a$}

Mediation analysis follows Zhao et al. (2010) and Nitzl et al. (2016), who revisit the traditional criteria for defining and testing mediation developed by Baron and Kenny (1986). From discarding $\mathrm{H} 2$ and $\mathrm{H} 3$, and following Zhao et al. (2010) it can be concluded that the effect of contractual governance on project performance is mediated by relational norms, partners' trust and partners contribution. In particular, there is an indirect-only mediation of relational norms between contractual governance and partners' contribution given the support for $\mathrm{H} 4$ and H5. Second, there is an indirect-only mediation of relational norms between contractual governance and partners' trust given the support for $\mathrm{H} 5$ and $\mathrm{H} 7$. The assessment of the total effect of contractual governance on project performance (Coeff. $=0.314, p<0.01$ ) provides support for $\mathrm{H} 8$ and H8a. The expected net relationship from Contractual Governance to Project Performance for H8a - including partners' trust (Coeff. $=0.078$ ) is lower than the path calculated for H8 -excluding partners' trust (Coeff. $=0.133){ }^{6}$ Additionally, the total effect of relational norms on project performance (Coeff. $=0.530, p<0.01)$ is higher than the total effect of partners' trust on project performance $($ Coeff. $=0.377, \mathrm{p}<0.01)$ (Table 4).

\subsection{Moderation analysis}

\subsubsection{Project complexity $H 9 a$ and $H 9 b$}

Two-stage continuous moderation analysis developed by Fassott et al. (2016) was used for assessing project complexity (Table 5). Results provide partial support for H9a and H9c. Project complexity positively moderates the relationship between partners' contribution and project performance (H1), as well as the relationship between contractual governance and relational norms (H5). For projects with an average level of complexity, the effect of partners' contribution on project performance scores $0.672(p<0.01)$, and the effect of contractual governance on

\footnotetext{
${ }^{5}$ Cohen $\mathrm{f}^{2}$ values above $0.35,0.15$ and 0.02 can be regarded as strong, moderate and weak, respectively (Henseler et al., 2016).

${ }^{6}$ The expected net relationship is calculated by multiplying the path value of the direct relationships included in the mediation chain. For $\mathrm{H} 8=\mathrm{a}_{1}^{*} \mathrm{~b}_{2}^{*} \mathrm{~d}_{1}=0.389 * 0.409 * 0.820=0.133$, and for $\mathrm{H} 8 \mathrm{a}=\mathrm{a}_{1}^{*} \mathrm{~b}_{1}^{*} \mathrm{c}_{1}^{*} \mathrm{~d}_{1}=$ $0.389 * 0.518 * 0.460 * 0.820=0.078$
} 
relational norms scores $0.369(\mathrm{p}<0.01)$. However, for those projects which complexity ranks one standard deviation above the average, the effect of partners' contribution on project performance increases up to 819 and the effect of contractual governance on relational norms increases up to 0.551 . This is due the moderating effect, which represents an additional 0.147 $(p<0.05)$ for the former, and an additional 0.182 for the latter $(\mathrm{p}<0.05)$.

\subsubsection{Contractual governance as moderator H10-H13}

Table 6 presents the results from modeling contractual governance as independent moderator of the relationships between: relational norms and partners' trust (H10), relational norms and partners' contribution (H11), partners' trust and partners' contribution (H12), and partners' contribution and project performance (H13). No moderation effect was significant.

\section{Discussion}

In line with theoretical insights from new institutional economics, this study brings into light the role of relational norms and trust as a relational mediators between contractual governance and partners contribution, and subsequently PPP project performance. A fundamental proposition states that informal institutions define the actual behaviours of players, while formal institutions influence the trajectory of informal institutions (Zenger et al., 2000). This study provides empirical evidence for the argument in project management literature that relational aspects mediate the effect of formal organizational designs on project coalitions' capacity to coordinate tasks, reach high levels of cooperation and increase project performance (Bresnen and Marshall, 2002; Chen and Manley, 2014; Joslin and Müller, 2016; Suprapto et al., 2015; Wu et al., 2017; Xue et al., 2016). Additionally, this study contributes to the current literature in PPPs, extensively focused on the direct relationship between contractual designs and project performance (de Castro e Silva Neto et al., 2016). The presented insights contribute to the call for examining how and when contractual and relational governance interact (Cao and Lumineau, 2015; Poppo and Zenger, 2002), moving away from the traditional dichotomy between substitution or complementarity.

Overall, this study provides evidence for conceptualizing the interplay from a procedural logic; as a sequence of relationships between contractual and relational governance elements. Relational governance elements (relational norms and trust) play their mediating role on the blue print provided by contractual governance elements, and translate these contractual provisions into contributions of project partners. Literature from process analysis has introduced enabling and compensating properties for describing the procedural logic of the interplay between governance mechanisms (Huber et al., 2013). In the following, these categories will be used for discussing the significance of the mediating effects found.

\subsection{Interpreting mediation: enabling mechanism}

The results of the study suggest that contractual governance enables relational governance providing a blue-print for behaviour, and then, relational governance compensates the inherent limitations of contractual governance. In comparison to the dichotomy of substitution and complementarity, compensating and enabling properties can logically coexist along a cascade of enablers from formal rules, to informal rules, psychological disposition, cooperative behaviour and satisfactory project results. Contractual governance shapes relational norms oriented to encourage mutual reliable attitudes based on trust. The latter functions as a complementary mediator of relational norms being the driver for collaborative practices and activities contributing to project performance. The enabling logic is based on the argument according to which formal rules constitute a tool available to managers through which informal rules can be shaped (Zenger et al., 2000). And these rules have an impact on individuals, predisposing them to engage in collaborative practices regardless the system of control in place. As the results of this study indicate, performance is the result of these cooperative practices, which are rather driven by trust and informal rules than formal enforceable rules.

In more detail, the study shows that an appropriate contractual design encourages the development of particular informal rules of relational exchange (Luo, 2002; Malhotra and Lumineau, 2011; Schepker et al., 2014). Space for negotiation upon a shared risk regime (CG4, CG5) might furniture the possibility to develop relational norms for dealing with changing circumstances that cannot be defined in the original contract (Das and Teng, 2001; Kivleniece and Quelin, 2012). The control dimension imposes a formal warrant (CG2) for defining relational norms that, actually allow partners to fulfil contractual obligations (Deakin and Wilkinson, 1998; Li et al., 2010; Woolthuis et al., 2005). The contract can trigger partners to focus on roles and responsibilities, being the initial point of reference for finding common ground between diverse perspectives for addressing problems (RN3 RN7) and solving misunderstandings (Malhotra and Lumineau, 2011). Relational norms initially emerge from the implementation of discrete contractual choice (Lincoln, 1982; Stevenson, 1990; Zenger et al., 2000), and then turn into an implicit understanding sanctioned by the strength of the informal ties built between partners. Trust from collaborative practices allows partners to increase mutual certainty about the scope and commitment on fulfilling their roles and responsibilities in the process of value co-creation (Kadefors, 2004; Wu et al., 2017).

\subsection{Interpreting mediation: compensating mechanism}

Nevertheless, the explained variance of relational norms and trust in the model is weak, implying the existence of other factors that account for these two variables (Kadefors, 2004). From this perspective, relational governance seems to operate as an independent factor that compensates contractual governance. Its role is encouraging contributions of the partners to the project, mediating the long-term contractual commitment and day-to-day collaborative interaction and activities which 
lead to project performance. This inference is empirically supported by the fact that the strongest effect measured in the model is the overall effect of relational norms on project performance (including the mediating effect of partners' trust and partners' contribution). The underlying logic of relational governance as a compensator of contractual governance must be understood in the light of the well-known incomplete nature of contractual forms (Gilson et al., 2010; Hart and Moore, 2008; Luo, 2002).

Relational norms compensate long-term contractual governance design by defining day-to-day collaborative micropractices, which nature and dynamics are not formalized as obligations to perform in advance (Bresnen and Marshall, 2002; Gibbons, 2010; Zheng et al., 2008). Relational norms directly influence partners' attitudes and behaviour to engage in collaborative activities in the process of delivering project outcomes (Lu et al., 2015; Olander et al., 2010). This may include informal rules for including different perspectives (RN2, RN4), in conjunction with arrangements for facilitating interaction (RN1), and the rule of finding a common ground to address conflicts (RN7). In practice, these elements facilitate the management of the project when future unfolds, and new issues emerge not regulated by the contract.

\subsection{Interpreting mediation: moderating effect of project complexity}

Finally, according to the moderation analysis project complexity is a positive moderator of the relationship between contractual governance and project relational norms, and partners' contribution and project performance. Depending on project complexity partners may experience a higher level of uncertainty about the extent to which initial contractual provisions hold in the future. Greater uncertainty requires stronger joint management, increasing the relevance of relational norms addressing substantive project issues. Then, both elements of relational governance (relational norms and trust) operate as a vehicle to compensate original contractual gaps given the necessarily incomplete nature of PPP contracts. On the other hand, the observed positive moderating effect of project complexity is also aligned with the theoretical proposition that higher levels of complexity require crafting tighter collaboration structures at the front-end of the project (Kivleniece and Quelin, 2012). From this perspective, partners intentionally establish contractual structures ex-ante that enable collaborative procedures to review project expectations and adapt partners' obligations ex-posts according to changing conditions.

\subsection{Managerial implications}

A managerial implication of this study is that partners in PPP projects should consider relational norms as a key aspect for organizing day-to-day partners' contributions and maintaining their commitment in typical long-term contract. For example, establishing relational norms allows seizing potential collaborative relations defined in contracts, including risk share regimes and transparent re-negotiations. This is particularly relevant when facing complexity: scenarios where partners are required to invest collaborative efforts to manage technological complexity, stakeholders' activism and impact of external events. PPP contracts can encourage project performance, but this positive effect requires to explicitly defining the role of relational norms and trust building process in and uncertainty management.

\subsection{Limitations}

The data of this study only includes PPP projects in the Netherlands restricting the possibility to generalize the conclusions to countries with different institutional configuration. In this regard, the typical corporatist tradition of Dutch institutional and cultural settings might accentuate the relevant of relational elements between public and private actors. Finally, causal inferences were based on assumed causal directions from literature with the expectation of strong feedbacks over time. In other words, it was assumed a one-direction relationship between contractual and relational governance, when their interplay is complex and certainly influences both ways. To overcome this limitation, it is required to implement longitudinal research designs based on the actuality of projects, as well as considering techniques, such as two-stage least squares (Henseler et al., 2016) or simulation methods such as System Dynamics (Sterman, 2000) to assess feedback loops over time and endogeneity. Additionally, this paper does not make statements about the objective performance of projects, and it explicitly frames "project performance" construct from the perspective of subjective satisfaction".

\section{Conclusion}

The inquiry on how to organize the interface between public and private parties in PPP project has its grounds on the challenge to unravel the complex interplay between contractual and relational governance in the process of value co-creation. Building on previous research of inter-organizational governance, relational contracting and Public-Private Partnerships, this study shows that relational governance with its elements of relational norms and partners' trust acts as a mediator between contractual governance and partners' contributions leading to project performance. According to the study findings, relational governance elements are suggested to operate as compensators of contractual governance, while contractual governance partially enables the operation of relational norms and the emergence of trust. This raises new research challenges such as defining the extent to which relational governance can be intentionally designed, how cross-project governance factors have an impact on governance at the project level, and how the interplay between relational and contractual governance is (re) constituted over the life-cycle of a PPP project.

\section{Conflict of Interest}

The authors declared no potential conflicts of interest with respect to the research, authorship, and/or publication of this article. 


\section{Acknowledgments}

The author(s) disclosed receipt of the following financial support for the research, authorship, and/or publication of this article: This article presents findings of the research project governance for smartening public-private partnerships implemented in collaboration with the Erasmus University Rotterdam and financed by the Netherlands Organization for Scientific Research (NWO; Dutch Research Council: No. 409-14- 014).

\section{Appendix A}

Annex 1

Inter-construct correlations.

\begin{tabular}{llllll}
\hline & CG & RN & PT & PC & PP \\
\hline Contractual governance & 1.000 & & & & \\
Project relational norms & 0.389 & 1.000 & & & \\
Partners trust & 0.340 & 0.518 & 1.000 & & \\
Partners' contribution & 0.389 & 0.676 & 0.697 & 1.000 & \\
Project performance & 0.365 & 0.571 & 0.527 & 0.837 & 1.000 \\
\hline
\end{tabular}

\section{References}

Ahola, T., Ruuska, I., Artto, K., Kujala, J., 2014. What is project governance and what are its origins? Int. J. Proj. Manag. 32 (8), 1321-1332.

Arranz, N., Arroyabe, J., 2012. Effect of formal contracts, relational norms and trust on performance of joint research and development projects. Br. J. Manag. 23 (4), 575-588.

Aubry, M., Richer, M.C., Lavoie-Tremblay, M., Cyr, G., 2011. Pluralism in PMO performance: the case of a PMO dedicated to a major organizational transformation. Proj. Manag. J. 42 (6), 60-77.

Atkinson, R., 1999. Project management: cost, time and quality, two best guesses and a phenomenon, its time to accept other success criteria. Int. J. Proj. Manag. 17 (6), 337-342.

Baron, R.M., Kenny, D.A., 1986. The moderator-mediator variable distinction in social psychological research: conceptual, strategic, and statistical considerations. J. Pers. Soc. Psychol. 51 (6), 1173.

Bing, L., Akintoye, A., Edwards, P.J., Hardcastle, C., 2005. The allocation of risk in PPP/PFI construction projects in the UK. Int. J. Proj. Manag. 23 (1), 25-35.

Blanken, A., 2008. Flexibility against Efficiency? An International Study on Value for Money in Hospital Concessions. University of Twente, Enschede.

Blau, P.M., 1964. Exchange and Power in Social Life. Transaction Publishers, New Brunswick.

Boardman, A.E., Greve, C., Hodge, G.A., 2015. Comparative analyses of infrastructure public-private partnerships. J. Comp. Policy Anal. Res. Pract. 17 (5), 441-447.

Borys, B., Jemison, D.B., 1989. Hybrid arrangements as strategic alliances: theoretical issues in organizational combinations. Acad. Manag. Rev. 14 (2), 234-249.

Brahm, F., Tarziján, J., 2015. Does complexity and prior interactions affect project procurement? Evidence from mining mega-projects. Int. J. Proj. Manag. 33 (8), 1851-1862.

Bresnen, M., Marshall, N., 2002. The engineering or evolution of co-operation? A tale of two partnering projects. Int. J. Proj. Manag. 20 (7), 497-505.

Bygballe, L.E., Håkansson, H., Jahre, M., 2013. A critical discussion of models for conceptualizing the economic logic of construction. Constr. Manag. Econ. 31 (2), 104-118.

Bygballe, L.E., Dewulf, G., Levitt, R.E., 2015. The interplay between formal and informal contracting in integrated project delivery. Eng. Proj. Organ. J. $5(1), 22-35$.
Cao, Z., Lumineau, F., 2015. Revisiting the interplay between contractual and relational governance: a qualitative and meta-analytic investigation. J. Oper. Manag. 33, 15-42.

Chang, C.Y., 2013. A critical review of the application of TCE in the interpretation of risk allocation in PPP contracts. Constr. Manag. Econ. 31 (2), 99-103.

Chen, L., Manley, K., 2014. Validation of an instrument to measure governance and performance on collaborative infrastructure projects. J. Constr. Eng. Manag. 140 (5), 355-377.

Churchill Jr., G.A., 1979. A paradigm for developing better measures of marketing constructs. J. Mark. Res. 64-73.

Cruz, C.O., Marques, R.C., 2013. Flexible contracts to cope with uncertainty in public-private partnerships. Int. J. Proj. Manag. 31 (3), 473-483.

Das, T.K., Teng, B.-S., 1998. Between trust and control: developing confidence in partner cooperation in alliances. Acad. Manag. Rev. 23 (3), 491-512.

Das, T.K., Teng, B.-S., 2001. Trust, control, and risk in strategic alliances: an integrated framework. Organ. Stud. 22 (2), 251-283.

Davis, K., 2014. Different stakeholder groups and their perceptions of project success. Int. J. Proj. Manag. 32 (2), 189-201.

de Castro e Silva Neto, D., Cruz, C.O., Rodrigues, F., Silva, P., 2016. Bibliometric analysis of PPP and PFI literature: overview of 25 years of research. J. Constr. Eng. Manag. 06016002.

Deakin, S., Wilkinson, F., 1998. Contract law and the economics of interorganizational trust. In: Lane, C., Bachmann, R. (Eds.), Trust Within and Between Organizations: Conceptual Issues and Empirical Applications. Oxford University Press, Oxford, New York.

Dijkstra, T.K., Henseler, J., 2015. Consistent partial least squares path modeling. MIS Q. 39 (2), 297-316.

Dubois, A., Gadde, L.E., 2002. The construction industry as a loosely coupled system: implications for productivity and innovation. Constr. Manag. Econ. 20 (7), 621-631.

Dyer, J.H., Chu, W., 2003. The role of trustworthiness in reducing transaction costs and improving performance: empirical evidence from the United States, Japan, and Korea. Organ. Sci. 14 (1), 57-68.

Eshuis, J., Van Woerkum, C., 2003. Trust and monitoring in governance processes: lessons from landscape management by farmers in a Dutch municipality. J. Environ. Policy Plan. 5 (4), 379-396.

Fassott, G., Fassott, G., Henseler, J., Henseler, J., Coelho, P.S., Coelho, P.S., 2016. Testing moderating effects in PLS path models with composite variables. Ind. Manag. Data Syst. 116 (9), 1887-1900.

Forsström, B., 2005. Value Co-creation in Industrial Buyer-Seller Partnerships: Creating and Exploiting Interdependencies: An Empirical Case Study. Abo Akademi University Press, Abo.

Gibbons, R., 2010. Inside organizations: pricing, politics, and path dependence. Annu. Rev. Econ. 2 (1), 337-365.

Gilson, R.J., Sabel, C.F., Scott, R.E., 2010. Braiding: the interaction of formal and informal contracting in theory, practice, and doctrine. Columbia Law Rev. 1377-1447.

Glaeser, E.L., Laibson, D.I., Scheinkman, J.A., Soutter, C.L., 2000. Measuring trust. Q. J. Econ. 115 (3), 811-846.

Goo, J., Kishore, R., Rao, H.R., Nam, K., 2009. The role of service level agreements in relational management of information technology outsourcing: an empirical study. MIS Q. 119-145.

Gopal, A., Koka, B.R., 2012. The asymmetric benefits of relational flexibility: evidence from software development outsourcing. MIS Q. 36 (2).

Granovetter, M., 1985. Economic action and social structure: the problem of embeddedness. Am. J. Sociol. 91 (3), 481-510.

Grimsey, D., Lewis, M.K., 2002. Evaluating the risks of public private partnerships for infrastructure projects. Int. J. Proj. Manag. 20 (2), 107-118.

Guo, F., Chang-Richards, Y., Wilkinson, S., Li, T.C., 2014. Effects of project governance structures on the management of risks in major infrastructure projects: a comparative analysis. Int. J. Proj. Manag. 32 (5), 815-826.

Hair Jr., J.F., Hult, G.T.M., Ringle, C., Sarstedt, M., 2013. A Primer on Partial Least Squares Structural Equation Modeling (PLS-SEM). Sage Publications, London.

Hart, O., Moore, J., 2008. Contracts as reference points. Q. J. Econ. 123 (1), 1-48.

Hartmann, A., Davies, A., Frederiksen, L., 2010. Learning to deliver serviceenhanced public infrastructure: balancing contractual and relational capabilities. Constr. Manag. Econ. 28 (11), 1165-1175. 
Henderson, L.S., Stackman, R.W., Lindekilde, R., 2016. The centrality of communication norm alignment, role clarity, and trust in global project teams. Int. J. Proj. Manag. 34 (8), 1717-1730.

Henseler, J., Ringle, C.M., Sinkovics, R.R., 2009. The use of partial least squares path modeling in international marketing. New Challenges to International Marketing. Emerald Group Publishing Limited, pp. 277-319.

Henseler, J., Dijkstra, T.K., Sarstedt, M., Ringle, C.M., Diamantopoulos, A., Straub, D.W., ... Calantone, R.J., 2014. Common beliefs and reality about PLS: comments on Rönkkö and Evermann (2013). Organ. Res. Methods 17 (2), 182-209.

Henseler, J., Hubona, G., Ray, P.A., 2016. Using PLS path modeling in new technology research: updated guidelines. Ind. Manag. Data Syst. 116 (1), 2-20.

Hodge, G.A., Greve, C., 2007. Public-private partnerships: an international performance review. Public Adm. Rev. 67 (3), 545-558.

Hodge, G.A., Greve, C., 2010. Public-private partnerships: governance scheme or language game? Aust. J. Public Adm. 69 (s1), S8-S22.

Hodge, G.A., Greve, C., 2017. On public-private partnership performance: a contemporary review. Public Works Manag. Policy 22 (1), 55-78.

Hoecht, A., 2004. Control in collaborative research and technology development: a case study in the chemical industry. J. Manag. Psychol. 19 (3), 218-234

Hoezen, M.E.L., 2012. The Competitive Dialogue Procedure: Negotiations and Commitment in Inter-Organisational Construction Projects. University of Twente, Enschede.

Huber, T.L., Fischer, T.A., Dibbern, J., Hirschheim, R., 2013. A process model of complementarity and substitution of contractual and relational governance in IS outsourcing. J. Manag. Inf. Syst. 30 (3), 81-114.

Joslin, R., Müller, R., 2016. The relationship between project governance and project success. Int. J. Proj. Manag. 34 (4), 613-626.

Kadefors, A., 2004. Trust in project relationships - inside the black box. Int. J. Proj. Manag. 22 (3), 175-182.

Kaiser, H.F., 1992. On Cliff's formula, the Kaiser-Guttman rule, and the number of factors. Percept. Mot. Skills 74 (2), 595-598.

Kaufmann, P.J., Dant, R.P., 1992. The dimensions of commercial exchange. Mark. Lett. 3 (2), 171-185

Ke, Y., Ling, F., Ning, Y., 2013. Public construction project delivery process in Singapore, Beijing, Hong Kong and Sydney. J. Financ. Manag. Prop. Constr. 18 (1), 6-25.

Ke, H., Cui, Z., Govindan, K., Zavadskas, E.K., 2015. The impact of contractual governance and trust on EPC projects in construction supply chain performance. Eng. Econ. 26 (4), 349-363.

Kivleniece, I., Quelin, B.V., 2012. Creating and capturing value in public-private ties: a private actor's perspective. Acad. Manag. Rev. 37 (2), 272-299.

Klijn, E.H., Koppenjan, J., 2016. The impact of contract characteristics on the performance of public-private partnerships (PPPs). Public Money Manag. 36 (6), 455-462.

Klijn, E.H., Steijn, B., Edelenbos, J., 2010. The impact of network management on outcomes in governance networks. Public Adm. 88 (4), 1063-1082.

Levitt, R., Henisz, W.J., Settel, D., 2009. Defining and mitigating the governance challenges of infrastructure project development and delivery. Paper Presented at the 2009 Conference on Leadership and Management of Construction.

Levitt, R., Garvin, M., Scott, W.R., Dewulf, G., Monk, A., South, A., 2014. Toward an integrated lifecycle governance framework for delivering civil infrastructure projects through public-private partnerships (P3). Paper Presented at the Engineering Project Organization Conference, Devil's Thumb Ranch, Colorado.

Li, J.J., Poppo, L., Zhou, K.Z., 2010. Relational mechanisms, formal contracts, and local knowledge acquisition by international subsidiaries. Strateg. Manag. J. 31 (4), 349-370

Lincoln, J.R., 1982. Intra-(and inter-) organizational networks. Res. Sociol. Organ. 1 (1), 1-38.

Ling, F., Ong, S., Ke, Y., Wang, S., Zou, P., 2014. Drivers and barriers to adopting relational contracting practices in public projects: comparative study of Beijing and Sydney. Int. J. Proj. Manag. 32 (2), 275-285.

Liu, W.-H., Cross, J.A., 2016. A comprehensive model of project team technical performance. Int. J. Proj. Manag. 34 (7), 1150-1166.
Lu, P., Guo, S., Qian, L., He, P., Xu, X., 2015. The effectiveness of contractual and relational governances in construction projects in China. Int. J. Proj. Manag. 33 (1), 212-222.

Lu, W., Zhang, L., Zhang, L., 2016. Effect of contract completeness on contractors' opportunistic behavior and the moderating role of interdependence. J. Constr. Eng. Manag. 142 (6), 04016004.

Lui, S.S., Ngo, H.-Y., 2004. The role of trust and contractual safeguards on cooperation in non-equity alliances. J. Manag. 30 (4), 471-485.

Luo, Y., 2002. Contract, cooperation, and performance in international joint ventures. Strateg. Manag. J. 23 (10), 903-919.

Macneil, I.R., 1980. The New Social Contract: An Inquiry into Modern Contractual Relations. Yale University Press, New Heaven.

McGuire, M., Agranoff, R., 2011. The limitations of public management networks. Public Admn. 89 (2), 265-284.

Malhotra, D., Lumineau, F., 2011. Trust and collaboration in the aftermath of conflict: the effects of contract structure. Acad. Manag. J. 54 (5), 981-998.

Malhotra, D., Murnighan, J.K., 2002. The effects of contracts on interpersonal trust. Adm. Sci. Q. 47 (3), 534-559.

Medlin, C., Quester, P., 2002. Inter-firm trust: two theoretical dimensions versus a global measure. Paper Presented at the Proceedings of the 18th Annual IMP Conference, Autumn 2002, Perth, Australia.

Ménard, C., 1996. The economics of hybrid organizations. J. Inst. Theor. Econ. 160 (3), 1-32.

Meng, X., 2012. The effect of relationship management on project performance in construction. Int. J. Proj. Manag. 30 (2), 188-198.

Ning, Y., Ling, F.Y.Y., 2013. Reducing hindrances to adoption of relational behaviors in public construction projects. J. Constr. Eng. Manag. 139 (11), 04013017.

Nitzl, C., Roldan, J.L., Cepeda, G., 2016. Mediation analysis in partial least squares path modeling: helping researchers discuss more sophisticated models. Ind. Manag. Data Syst. 116(9):1849-1864. https://doi.org/10.1108/IMDS-072015-0302.

OECD, 2012. Recommendation of the Council on Principles for Public Governance of Public-Private Partnerships. (C(2012)86). Retrieved from. http://www.oecd.org/governance/budgeting/PPP-Recommendation.pdf.

Olander, H., Hurmelinna-Laukkanen, P., Blomqvist, K., Ritala, P., 2010. The dynamics of relational and contractual governance mechanisms in knowledge sharing of collaborative R\&D projects. Knowl. Process. Manag. 17 (4), 188-204

Poppo, L., Zenger, T., 2002. Do formal contracts and relational governance function as substitutes or complements? Strateg. Manag. J. 23 (8), 707-725.

Procaccino, J.D., Verner, J.M., Shelfer, K.M., Gefen, D., 2005. What do software practitioners really think about project success: an exploratory study. J. Syst. Softw. 78 (2), 194-203.

Ring, P., Van de Ven, A., 1994. Developmental processes of cooperative interorganizational relationships. Acad. Manag. Rev. 19 (1), 90-118.

Roehrich, J.K., 2009. The Dynamics of Inter-Organisational Governance: Contractual and Relational Mechanisms in Public-Private Supply Arrangements. University of Bath, Bath.

Rönkkö, M., Ylitalo, J., 2011. PLS Marker Variable Approach to Diagnosing and Controlling for Method Variance.

Rousseau, D.M., Sitkin, S.B., Burt, R.S., Camerer, C., 1998. Not so different after all: A cross-discipline view of trust. Acad. Manag. Rev. 23 (3), 393-404.

Rufín, C., Rivera-Santos, M., 2012. Between commonweal and competition: understanding the governance of public-private partnerships. J. Manag. 38 (5), 1634-1654.

Ryall, M.D., Sampson, R.C., 2009. Formal contracts in the presence of relational enforcement mechanisms: evidence from technology development projects. Manag. Sci. 55 (6), 906-925.

Sahmer, K., Hanafi, M., Qannari, M., 2006. Assessing unidimensionality within PLS Path Modeling Framework. From Data and Information Analysis to Knowledge Engineering, pp. 222-229.

Schepker, D.J., Oh, W.-Y., Martynov, A., Poppo, L., 2014. The many futures of contracts moving beyond structure and safeguarding to coordination and adaptation. J. Manag. 40 (1), 193-225.

Scott, W.R., 1983. Organizations and Organizing: Rational, Natural and Open Systems Perspectives. Prentice Hall, Englewood Cliffs. 
Scott, R.E., Triantis, G.G., 2005. Incomplete contracts and the theory of contract design. Case West. Reserv. Law Rev. 56, 187.

Segars, A.H., Grover, V., 1998. Strategic information systems planning success: an investigation of the construct and its measurement. MIS Q. 139-163.

Sterman, J., 2000. Business Dynamics: Systems Thinking and Modeling for a Complex World. vol. 19. Irwin/McGraw-Hill, Boston.

Stevenson, W.B., 1990. Formal structure and networks of interaction within organizations. Soc. Sci. Res. 19 (2), 113-131.

Strong, K., Chhun, S., 2014. Complex governance system issues for transportation renewal projects. Urban Plan. Transp. Res. 2 (1), 233-246.

Suprapto, M., Bakker, H.L.M., Mooi, H.G., 2015. Relational factors in owner-contractor collaboration: the mediating role of teamworking. Int. J. Proj. Manag. 33 (6), 1347-1363.

Tang, L., Shen, Q., Cheng, E., 2010. A review of studies on public-private partnership projects in the construction industry. Int. J. Proj. Manag. 28 (7), 683-694.

Teisman, G., van Buuren, A., Gerrits, L.M., 2009. Managing Complex Governance Systems. Routledge.

Thompson, J.D., 1967. Organizations in Action: Social Science Bases of Administrative Theory. Transaction Publishers.

Van den Hurk, M., Verhoest, K., 2015. The governance of public-private partnerships in sports infrastructure: interfering complexities in Belgium. Int. J. Proj. Manag. 33 (1), 201-211.

Verweij, S., Klijn, E.H., Edelenbos, J., Van Buuren, A., 2013. What makes governance networks work? A fuzzy set qualitative comparative analysis of 14 Dutch spatial planning projects. Public Adm. 91 (4), 1035-1055.

Verweij, S., Gerrits, L.M., 2015. How satisfaction is achieved in the implementation phase of large transportation infrastructure projects: A qualitative comparative analysis into the A2 tunnel project. Public Works Management \& Policy 20 (1), 5-28.

Verweij, S., 2015. Once the Shovel Hits the Ground. Erasmus Rotterdam University.

Villani, E., Greco, L., Phillips, N., 2015. Business Models and Institutional Complexity: Understanding Value Creation in Healthcare Sector PublicPrivate Partnerships.

Wang, H.-K., Tseng, J.-F., Yen, Y.-F., 2014. How do institutional norms and trust influence knowledge sharing? An institutional theory. Innovation 16 (3), 374-391.
Wang, Y., Chen, Y., Fu, Y., Zhang, W., 2017. Do prior interactions breed cooperation in construction projects? The mediating role of contracts. Int. J. Proj. Manag. 35 (4), 633-646.

Winch, G.M., 2010. Managing Construction Projects. John Wiley \& Sons.

Woolthuis, R.K., Hillebrand, B., Nooteboom, B., 2005. Trust, contract and relationship development. Organ. Stud. 26 (6), 813-840

World-Bank, 2014. Public-private partnerships reference guide 2.0. Retrieved from. http://www-wds.worldbank.org/external/default/WDSContentServer/WDSP/IB/ 2014/09/08/000442464_20140908133431/Rendered/PDF/903840PPP0Refe0 Box385311B000PUBLIC0.pdf.

Wu, A., Wang, Z., Chen, S., 2017. Impact of specific investments, governance mechanisms and behaviors on the performance of cooperative innovation projects. Int. J. Proj. Manag. 35 (3), 504-515.

Xue, J., Yuan, H., Shi, B., 2016. Impact of contextual variables on effectiveness of partnership governance mechanisms in megaprojects: case of Guanxi. J. Manag. Eng. 33 (1), 04016034.

Yang, Z., Su, C., Fam, K.-S., 2012. Dealing with institutional distances in international marketing channels: governance strategies that engender legitimacy and efficiency. J. Mark. 76 (3), 41-55.

Zenger, T.R., Lazzarini, S.G., Poppo, L., 2000. Informal and formal organization in new institutional economics. In: Ingram, P., Silverman, B. S. (Eds.), The New Institutionalism in Strategic Management. Emerald Group Publishing Limited, Bingley, pp. 277-305.

Zhang, Z., Wan, D., Jia, M., Gu, L., 2009. Priorities, shared values and cooperation in public-private partnerships. Manag. Organ. Rev. 5 (3), 353-374.

Zhang, S., Zhang, S., Gao, Y., Ding, X., 2016. Contractual governance: effects of risk allocation on contractors' cooperative behavior in construction projects. J. Constr. Eng. Manag. 142 (6), 04016005.

Zhao, X., Lynch Jr., J.G., Chen, Q., 2010. Reconsidering Baron and Kenny: myths and truths about mediation analysis. J. Consum. Res. 37 (2), 197-206

Zheng, J., Roehrich, J.K., Lewis, M.A., 2008. The dynamics of contractual and relational governance: evidence from long-term public-private procurement arrangements. J. Purch. Supply Manag. 14 (1), 43-54.

Zhou, Y., Zhang, X., Zhuang, G., Zhou, N., 2015. Relational norms and collaborative activities: roles in reducing opportunism in marketing channels. Ind. Mark. Manag. 46, 147-159. 